\title{
MODEL LOYALITAS PELANGGAN BERBASIS REPUTASI MEREK DAN KEPUASAN TERHADAP PRODUK FARMASI DI APOTEK KOTA MEDAN, SUMATERA UTARA
}

\section{CUSTOMER LOYALTY MODEL BASED ON BRAND REPUTATION AND SATISFACTION WITH PHARMACEUTICAL PRODUCTS IN PHARMACY AT MEDAN CITY, NORTH SUMATRA}

\author{
Aji Tetuko ${ }^{1 *}$, Diesty Anita Nugraheni ${ }^{2}$ \\ ${ }^{1}$ Farmasi STIKES Cendekia Utama Kudus, \\ Jl. Lingkar Raya Pati Km 5, Kudus, Jawa Tengah \\ ${ }^{2}$ Farmasi Universitas Islam Indonesia Yogyakarta \\ Jl. Kaliurang No.Km. 14,5, Sleman, Yogyakarta \\ *Penulis Korespondensi, e-mail: ajitetuko28@gmail.com
}

\begin{abstract}
ABSTRAK
Loyalitas pada pelanggan disebabkan oleh pengaruh kepuasan atau ketidakpuasan dengan merek tersebut yang terakumulasi secara terus-menerus. Selain itu, loyalitas mencerminkan komitmen psikologis terhadap merek tertentu. Perilaku pembelian ulang terhadap merek yang sama bisa dikarenakan memang hanya satu-satunya merek yang tersedia, termurah, atau sebab lainnya. Penelitian bertujuan untuk menguji model pengaruh reputasi merek dan kepuasan pelanggan terhadap loyalitas pelanggan. Penelitian mengikuti rancangan penelitian survei non-experimental pada apotek-apotek di kota Medan. Pengambilan sampel dilakukan dengan teknik purposive sampling. Sampel yang diambil dibatasi waktu pengambilan sampel yaitu bulan Januari-Desember 2012. Subyek penelitian yaitu pelanggan yang memiliki wewenang dalam melakukan pembelian di apotek, paling sedikit sekali setiap bulannya dalam selang waktu antara bulan Januari-Desember 2012 melalui PBF X Medan. Analisis data menggunakan uji regresi linier berganda. Sampel yang digunakan berjumlah 98 responden dengan mayoritas adalah wanita, usia 31-40 tahun, pekerjaan asisten apoteker, dan berpendidikan tamat SMA. Hasil analisis regresi berganda pada variabel reputasi merek dan kepuasan pelanggan mempunyai pengaruh yang positif dan signifikan masing-masing sebesar 0,32 dan 0,24 terhadap loyalitas pelanggan produk " $X$ " pada apotek di kota Medan. Model persamaan regresi yang dihasilkan yaitu $\mathrm{Y}=11,318+0,32 \mathrm{X}_{1}+0,243 \mathrm{X}_{2}$. Maknanya adalah $\mathrm{Y}=$ loyalitas pelanggan; $\mathrm{X}_{1}=$ reputasi merek; dan $\mathrm{X}_{2}=$ kepuasan pelanggan. Kesimpulannya adalah reputasi merek dan kepuasan pelanggan secara bersama-sama mempunyai pengaruh yang signifikan sebesar $18,4 \%$ terhadap loyalitas pelanggan produk " $X$ " pada apotek di kota Medan.
\end{abstract}

Kata Kunci: reputasi merek, kepuasan pelanggan, loyalitas pelanggan, produk farmasi, apotek

\section{ABSTRACT}

Loyalty to customers were caused by the influence of satisfaction or dissatisfaction with the brand that accumulates continuously. In addition, loyalty reflects a psychological commitment to a particular brand. The behavior of repurchasing the same brand because it was the only brand available, the cheapest, or the other reasons. This study aims to examine the model of 
the influence of brand reputation and customer satisfaction on customer loyalty. The study followed a non-experimental survey research design at pharmacies in the city of Medan. Sampling was done by purposive sampling technique. The samples taken were limited by sampling time, in January-December 2012. The research subjects were customers who had the authority to make purchases at pharmacies, at least once every month in the interval between January-December 2012 through PBF X Medan. Data analysis using multiple linear regression test. The sample used were 98 respondents with the majority being women, aged 31-40 years, working as pharmacist assistants, and having high school education. The results of multiple regression analysis on the variable brand reputation and customer satisfaction have a positive and significant effect of 0.32 and 0.24 respectively on customer loyalty product " $X$ " at pharmacies in the city of Medan. The resulting regression equation model is $Y$ $=11.318+0.32 X_{1}+0.243 X_{2}$. Where $Y=$ customer loyalty; $X_{1}=$ brand reputation; and $X_{2}=$ customer satisfaction. The conclusion is brand reputation and customer satisfaction together have a significant effect of $18.4 \%$ on customer loyalty for product " $X$ " at pharmacies in the city of Medan.

Keywords: brand reputation, customer satisfaction, customer loyalty, pharmaceutical products, pharmacy

\section{PENDAHULUAN}

Dalam konteks merek, loyalitas mencerminkan komitmen psikologis terhadap merek tertentu, sedangkan perilaku pembelian ulang semata-mata menyangkut pembelian merek tertentu yang sama secara berulang kali bisa dikarenakan memang hanya satu-satunya merek yang tersedia, merek termurah, dan sebagainya (Tjiptono, 2002).

Beberapa lini produk X yang terjual di kota Medan pada tahun 2012 mengalami penurunan dari tahun sebelumnya. Diantaranya adalah obat OTC, ethical, dan kosmetik. Hal ini mempengaruhi total penjualan produk secara keseluruhan dimana terjadi penurunan penjualan produk sebesar Rp2.232.804.370 atau 6,78\% dibandingkan penjualan tahun 2011. Hal ini perlu untuk dilakukan kajian untuk mengetahui penyebab permasalahan tersebut. Kemungkinan hal ini terjadi karena reputasi merek produk X menurun dari tahun ke tahun di kota Medan, selain itu faktor kepuasan pelanggan juga ikut mempengaruhinya. Akibatnya banyak pelanggan yang beralih ke produk dari perusahaan lain, yang juga mempunyai makna bahwa loyalitas pelanggan mulai berkurang.

Loyalitas pelanggan dipengaruhi berbagai macam faktor yaitu kepuasan pelanggan, reputasi merek, hubungan dengan pelanggan, harga, waktu tunggu, keandalan, kualitas pelayanan, reputasi perusahaan, nilai yang diterima pelanggan, dan kepercayaan (trust) (Kumar et al., 2011). Selnes (1993) dalam penelitiannya mengemukakan bahwa reputasi merek adalah penggerak utama loyalitas pelanggan, dan karenanya perusahaan berusaha untuk 
meningkatkan ekuitas merek (Selnes, 1993). Kualitas produk tidak hanya mempengaruhi kepuasan pelanggan, tetapi juga reputasi merek. Penelitian lain oleh Sunarto (2006) menyebutkan kualitas pelayanan, reputasi merek, kepuasan pelanggan berpengaruh terhadap loyalitas (Sunarto, 2006). Menurut penelitian Musanto (2004) faktor yang secara signifikan mempengaruhi loyalitas pelanggan adalah sales experience (pengalaman karyawan) (Musanto, 2004). Berbeda dengan Musanto, Hanan dan Karp memasukkan sales experience dalam kategori kepuasan pelanggan dalam penelitiannya (Hanan and Karp, 1991). Beberapa penelitian tersebut menunjukkkan bahwa reputasi merek dan kepuasan pelanggan adalah faktor penting yang mempengaruhi loyalitas pelanggan.

Kepuasan pelanggan dan loyalitas pelanggan adalah pondasi utama dalam strategi marketing. Hal ini dikarenakan keduanya efektif menggambarkan bagaimana perusahaan memberikan nilai kepada pelanggannya. Selain itu, keduanya merupakan faktor penting untuk pemasaran produk sekarang maupun masa depan sehingga dapat meningkatkan performa finansial perusahaan (Bae, 2011).

Penelitian dari Putra (2011) menyatakan bahwa pengukuran tingkat kepuasan pelanggan terdiri dari lima dimensi yaitu Tangible, Reability, Responsiveness, Assurance, dan Empathy dengan menggunakan model Service Quality (Putra, 2011). Menurut Hanan dan Karp (1991), pengukuran kepuasan pelanggan terdiri dari delapan indikator yaitu kualitas produk, hubungan antara nilai sampai pada harga, bentuk produk, keandalan, jaminan, respon dan cara pemecahan masalah, pengalaman karyawan, serta kemudahan dan kenyamanan (Hanan and Karp, 1991).

Kepuasan pelanggan dianggap sebagai prediktor kuat variabel perilaku seperti loyalitas pelanggan, word of mouth, dan niat pembelian Kembali (Eggert \& Ulaga, 2002). Banyak peneliti dan literatur telah melaporkan bahwa ada korelasi positif antara kepuasan pelanggan, retensi pelanggan dan loyalitas pelanggan yang akhirnya mengarah pada (Anderson and Sullivan, 1993; Hallowell, 1996; J L Heskett and Jones, 1994; Mittal et al., 2001; Parasuraman et al., 1985). Tingkat kepuasan pelanggan meningkatkan loyalitas dengan membangun reputasi merek yang positif (Anderson, 1994). Reputasi merek berperan dalam mengembangkan loyalitas pelanggan (Andreassen and Lindestad, 1998). Selnes (1993) dalam penelitiannya mengemukakan bahwa reputasi merek dan kepuasan pelanggan adalah penentu penting dari loyalitas pelanggan. Menurut Selnes (1993), reputasi merek lebih kuat mempengaruhi loyalitas pelanggan dibandingkan kepuasan pelanggan, namun Andreassen 
(1994) menyatakan bahwa reputasi mempunyai pengaruh pada kepuasan dan loyalitas pelanggan (Andreassen, 1994; Selnes, 1993). Perbedaan ini menjadi research gap yang menarik untuk diteliti lebih lanjut bagaimana sebenarnya pengaruh reputasi merek dan kepuasan pelanggan pada loyalitas pelanggan. Tujuan penelitian ini adalah untuk menguji model pengaruh reputasi merek dan kepuasan pelanggan terhadap loyalitas pelanggan.

\section{METODE PENELITIAN}

Penelitian dilakukan dengan metode penelitian survei non-experimental pada apotekapotek di kota Medan. Data diambil dengan 2 langkah. Pertama, pengambilan data dilakukan dengan mengumpulkan data pelanggan produk " $X$ " melalui PBF X Medan di kota Medan yang memenuhi kriteria subyek penelitian. Kedua, pengambilan data menggunakan kuesioner pada pelanggan yang memenuhi kriteria subyek penelitian.

\section{Populasi dan Sampel}

Populasi adalah seluruh apoteker atau tenaga teknis kefarmasian di apotek wilayah Kota Medan. Pengambilan sampel dilakukan dengan teknik purposive sampling, yaitu sampel dipilih karena memenuhi kriteria menjadi subyek penelitian. Kriteria sampel yaitu individu yang memiliki wewenang dalam melakukan pembelian atau pengadaan barang di apotek wilayah kota Medan. Apotek yang menjadi pelanggan PBF X dipilih sebagai tempat penelitian, dimana apoteker ataupun tenaga teknis kefarmasian yang mempunyai wewenang dalam melakukan pembelian di apotek tersebut menjadi subyek penelitian ini.

Kriteria inklusi yaitu:

a. Pelanggan yang memiliki wewenang dalam melakukan pembelian di apotek dan bersedia mengisi kuesioner dengan lengkap.

b. Apotek yang melakukan pembelian paling sedikit sekali setiap bulan dalam selang waktu antara bulan Januari - Desember 2012 melalui PBF X cabang Medan

Kriteria eksklusi:

Kuesioner tidak diisi dengan lengkap

Instrument penelitian

Instrument yang digunakan adalah kuesioner pelanggan. Kuesioner dikembangkan oleh peneliti berdasarkan penelusuran literatur-literatur sebelumnya. Kuesioner menggunakan skala sikap, yakni skala Likert dengan rentang 1 sampai 5. Pada skala Likert, setiap 
pertanyaan berisi lima alternatif jawaban dengan gradasi dari positif sampai dengan negatif. Terdapat 20 pernyataan sikap dalam kuesioner ini yang terdiri dari variabel merek (6 pernyataan), kepuasan pelanggan ( 7 pernyataan) dan loyalitas pelanggan (7 pernyataan). Penilaian skor kuesioner dibedakan antara pertanyaan favorable dan unfavorable. Perhitungan skor dalam pertanyaan favorable adalah sangat setuju $=5$, setuju $=4$, netral $/$ biasa saja $=3$, tidak setuju $=2$, dan sangat tidak setuju $=1$, sedangkan pada pertanyaan unfavorable adalah sangat setuju $=1$, setuju $=2$, netral/biasa saja $=3$, tidak setuju $=4$, dan sangat tidak setuju $=5$.

Pengujian validitas dan reliabilitas dilakukan kepada 32 responden agar diperloleh kuesioner yang valid dan reliabel. Pengukuran validitas kuesioner penelitian dilakukan dengan menggunakan uji statistik Pearson Product Moment. Uji validitas dilakukan dengan membandingkan antara nilai $r$ hitung dengan $r$ tabel. Jika nilai $r$ hitung lebih besar daripada $r$ tabel dan bernilai positif, maka instrumen tersebut dikatakan valid (Ghozali, 2006). Hasilnya adalah seluruh item pernyataan dalam kuesioner penelitian dinyatakan valid karena $\mathrm{r}$ hitung > dari $\mathrm{r}$ tabel $(0,349)$. Pengujian reliabilitas menggunakan teknik reliability analysist Alpha Cronbach. Nilai reliabilitas variabel ditunjukkan oleh koefisien Cronbach Alpha. Suatu variabel dikatakan reliabel apabila koefisien Cronbach Alpha > 0,60 (Ghozali, 2006). Hasil pengujian reabilitas menunjukkan data pada setiap variabel tersebut reliabel karena pada baik reputasi merek, kepuasan, dan loyalitas pelanggan mempunyai nilai koefisien Cronbach Alpha $>0,60$.

\section{Analisis Data}

Analisis data dilakukan menggunakan model analisis regresi linier berganda (multiple regression analysis). Analisis regresi berganda dalam penelitian ini bertujuan untuk mengetahui besarnya pengaruh variabel independen (reputasi merek, kepuasan pelanggan) terhadap variabel dependen (loyalitas pelanggan). Dalam penelitian ini loyalitas pelanggan sebagai variabel terikat/dependen yang disimbolkan dengan $\mathrm{Y}$ terhadap variabel bebas/independen yang terdiri dari reputasi merek (X1), dan kepuasan pelanggan (X2). Model persamaan regresi yang diperoleh kemudian dilakukan interpretasi terhadap dengan pengujian statistik yaitu terdiri dari Koefisien Determinasi $\left(\mathrm{R}^{2}\right)$, Uji F, dan Uji t. Pertama, dilakukan analisis untuk mengetahui pengaruh atau hubungan secara parsial antara reputasi merek atau kepuasan pelanggan dengan loyalitas pelanggan. Pengujian hipotesisnya menggunakan uji t. Uji t adalah uji secara individual semua koefisien regresi yang bertujuan untuk mengetahui 
besarnya pengaruh dari masing-masing variabel independen terhadap variabel dependen. Sampel yang diambil pada penelitian ini adalah 98 responden. Berdasarkan taraf kepercayaan (degree of freedom/df) yang dipilih sebesar 95\% dan $\alpha=5 \%$ didapat nilai t tabel adalah sebesar t0,05/2(98-2) = 1,66. Kedua, untuk mengetahui pengaruh secara simultan antara variabel reputasi merek dan kepuasan pelanggan dengan loyalitas pelanggan. Untuk mengetahui apakah benar variabel independen (reputasi merek dan kepuasan pelanggan) secara bersama-sama mempengaruhi variabel dependen (loyalitas pelanggan), maka dilakukan pengujian model dengan uji $\mathrm{F}$ dari keluaran ANOVA. Uji $\mathrm{F}$ adalah uji untuk mengetahui besarnya pengaruh variabel independen terhadap variabel dependen secara bersama-sama. Sampel yang diambil pada penelitian ini adalah 98 responden, dengan taraf kepercayaan $95 \%$ dan $\alpha=5 \%$ diperoleh angka $\mathrm{F}$ tabel sebesar 3,09.

\section{HASIL DAN PEMBAHASAN}

Peneliti telah menyebar kuisioner yang berisi pertanyaan tertulis kepada 98 responden dengan jumlah 27 pertanyaan (terdiri atas 6 pertanyaan mengenai profil pelanggan dan 21 pertanyaan mengenai reputasi merek, kepuasan pelanggan, dan loyalitas pelangggan terhadap produk “X”). Kuesioner tersebut telah dilakukan uji validitas dan reabilitas secara statistic dan dinyatakan valid dan reliabel.

Loyalitas pelanggan merupakan tujuan strategis utama dan fokus dalam pemasaran. Loyalitas pelanggan dipengaruhi oleh beberapa faktor, antara lain reputasi merek dan kepuasan pelanggan. Dalam situasi dimana isyarat intrinsik dari produk atau jasa yang ambigu, reputasi merek merupakan pendorong terkuat loyalitas pelanggan dibandingkan dengan kepuasan pelanggan. Indikator yang digunakan untuk mengukur variabel reputasi merek diacu dari penelitian Selnes (1993) adalah nama baik, reputasi dibanding pesaing, dikenal luas dan kemudahan diingat. Indikator-indikator tersebut digunakan dalam penelitian ini, dan hasilnya dapat digambarkan pada Tabel 1.

Hasil analisis menunjukkan bahwa nilai indikator paling besar yaitu nama baik. Nama baik adalah persepsi baik dari pelanggan tentang bagaimana nama yang berhasil dibangun oleh perusahaan. Hal ini berarti nama produk " $X$ " dinilai baik oleh pelanggan apotek di Kota Medan. Rata-rata nilai reputasi merek dalam penelitian ini yaitu 3,83 atau dapat dikatakan rata-rata pelanggan "setuju" mengenai produk "X" mempunyai reputasi merek yang baik. 
Tabel 1. Gambaran reputasi merek produk "X" pada apotek di Kota Medan

\begin{tabular}{cc}
\hline Indikator & Mean \pm SD \\
\hline Nama baik & $4,12 \pm 0,542$ \\
Reputasi dibanding pesaing & $3,85 \pm 0,664$ \\
Dikenal luas & $3,94 \pm 0,589$ \\
Mudah diingat & $3,82 \pm 0,581$ \\
Mudah diingat $^{*}$ & $3,88 \pm 0,630$ \\
Dikenal luas $^{*}$ & $3,80 \pm 0,574$ \\
Total reputasi merk & $23,40 \pm 2,30$ \\
\hline
\end{tabular}

Keterangan : $\mathrm{SD}==$ Standard Deviation $\left.;{ }^{*}\right)=$ item pertanyaan kedua

Kotler berpendapat bahwa kepuasan oleh perasaan kesenangan atau kekecewaan adalah dari hasil membandingkan perfoma produk yang diterima dalam hubungannya dengan perkiraannya. Indikator yang digunakan untuk mengukur variabel kepuasan pelanggan adalah kualitas produk, hubungan antara nilai sampai pada harga, bentuk produk, keandalan, jaminan, respon dan cara pemecahan masalah, pengalaman karyawan, serta kemudahan dan kenyamanan (Kotler and Keller, 2006). Nilai dari indikator kepuasan pelanggan ditunjukkan dalam Tabel 2. Hasil analisis menunjukkan bahwa nilai indikator kepuasan pelanggan paling besar yaitu kualitas produk. Kualitas produk yaitu mutu dari semua komponen-komponen yang membentuk produk, sehingga produk tersebut mempunyai nilai tambah. Hal ini berarti pelanggan merasa puas terhadap kualitas produk " $\mathrm{X}$ ", dimana mutu produk tersebut dikatakan baik oleh pelanggan. Nilai indikator yang paling kecil yaitu pada "hubungan nilai dengan harga", dimana sebagian pelanggan menganggap harga produk " $\mathrm{X}$ " relatif tidak murah atau mahal. Rata-rata nilai kepuasan pelanggan dalam penelitian ini yaitu 3,71 atau dapat dikatakan rata-rata pelanggan merasa puas terhadap produk " $\mathrm{X}$ ".

Tabel 2. Gambaran kepuasan pelanggan produk "X" pada Apotek di Kota Medan

\begin{tabular}{ll}
\hline Indikator & Mean \pm SD \\
\hline Kualitas produk & $4,10 \pm 0,442$ \\
Hubungan nilai sampai harga & $3,26 \pm 0,764$ \\
Bentuk produk & $3,32 \pm 0,667$ \\
Keandalan & $3,70 \pm 0,629$ \\
Jaminan & $3,66 \pm 0,759$ \\
Respon dan cara pemecahan masalah & $3,88 \pm 0,561$ \\
Pengalaman karyawan & $3,85 \pm 0,632$ \\
Kemudahan dan kenyamanan & $3,89 \pm 0,515$ \\
Total kepuasan & $29,65 \pm 2,549$ \\
\hline
\end{tabular}

Keterangan : SD = =Standard Deviation 
Kekuatan hubungan antara variabel reputasi merek dan kepuasan pelanggan dengan loyalitas pelanggan, dapat diketahui dengan menggunakan koefisien korelasi Pearson seperti ditunjukkan dalam Tabel 3.

Tabel 3. Hubungan (Korelasi) antara variabel reputasi merek dan kepuasan pelanggan dengan loyalitas pelanggan

\begin{tabular}{llc}
\hline Variabel & Pearson Correlation & p \\
\hline Reputasi Merek & 0,352 & $0,000^{*}$ \\
Kepuasan Pelanggan & 0,314 & $0,001^{*}$ \\
\hline Keterangan: Analisis Regresi Linier Berganda; $\mathrm{p}<0,05$ &
\end{tabular}

Tabel 3 menunjukkan nilai koefisien korelasi reputasi merek adalah 0,352, artinya hubungan reputasi merek dan loyalitas pelanggan termasuk kategori cukup kuat dan searah. Hal ini berarti jika variabel reputasi merek meningkat maka loyalitas pelanggan akan meningkat. Nilai koefisien korelasi kepuasan pelanggan adalah 0,314 , artinya hubungan kepuasan pelanggan dan loyalitas pelanggan termasuk kategori cukup kuat dan searah. Artinya jika variabel reputasi merek meningkat maka loyalitas pelanggan akan meningkat pula. Hubungan antar kedua variabel ini signifikan $(\mathrm{p}<0,05)$.

Analisis pengaruh reputasi merek dan kepuasan pelanggan terhadap loyalitas pelanggan dilakukan menggunakan analisis regresi linier berganda (multiple regression analysis). Regresi linier berganda merupakan perluasan dari regresi linier sederhana dengan dua atau lebih variabel bebas yang digunakan sebagai predictor dan satu variabel tergantung yang diprediksi. Analisis selanjutnya adalah mencari model persamaan regresi berganda dari kasus yang diteliti. Dalam penelitian ini loyalitas pelanggan sebagai variabel terikat/dependen yang disimbolkan dengan Y terhadap variabel bebas/independen yang terdiri dari reputasi merek $\left(\mathrm{X}_{1}\right)$, dan kepuasan pelanggan $\left(\mathrm{X}_{2}\right)$. Nilai koefisien masing-masing variabel dapat dilihat dari nilai Beta (B) yang tercantum pada Tabel 4.

Tabel 4. Analisis regresi linier berganda loyalitas pelanggan

\begin{tabular}{|c|c|c|c|c|}
\hline \multirow{2}{*}{ Variabel } & \multicolumn{2}{|c|}{ Unstandardized Coefficients } & \multirow{2}{*}{$\mathbf{T}$} & \multirow{2}{*}{$\begin{array}{l}\text { Signifikansi } \\
\text { (p) }\end{array}$} \\
\hline & $\boldsymbol{B}$ & SE & & \\
\hline Konstanta & 11,318 & 3,228 & 3,506 & 0,001 \\
\hline Reputasi Merek & 0,320 & 0,102 & 3,138 & 0,002 \\
\hline Kepuasan Pelanggan & 0,243 & 0,092 & 2,631 & 0,010 \\
\hline
\end{tabular}

Keterangan: Analisis Regresi Linier Berganda; $\mathrm{B}=\mathrm{Beta} ; \mathrm{SE}=$ Standard Error; $\mathrm{p}<0,05$ 
Analisis regresi linier berganda menghasilkan model persamaan regresi loyalitas pelanggan sebagai berikut:

$$
\begin{aligned}
Y & =a+b_{1} x_{1}+b_{2} x_{2} \\
& =11,318+0,32 x_{1}+0,243 x_{2}
\end{aligned}
$$

Nilai a adalah angka Beta konstanta, yang berarti besarnya loyalitas pelanggan saat nilai reputasi merek dan kepuasan pelanggan sama dengan nol (0). Nilai $b_{1}$ adalah koefisien Beta reputasi merek, yang berarti bahwa setiap penambahan satu tingkat reputasi merek, maka loyalitas pelanggan akan naik sebesar 0,32. Nilai $b_{2}$ adalah koefisien Beta kepuasan pelanggan, yang berarti bahwa setiap penambahan satu tingkat kepuasan pelanggan, maka loyalitas pelanggan akan naik sebesar 0,243.

Variabel reputasi merek dan kepuasan pelanggan secara parsial dapat digunakan untuk memprediksi variabel loyalitas pelanggan. Model tersebut bermakna jika terdapat penambahan satu tingkat reputasi merek produk "X", maka loyalitas pelanggan akan naik sebesar 0,32. Begitu pula jika terjadi penambahan satu tingkat kepuasan pelanggan produk "X", maka loyalitas pelanggan akan naik sebesar 0,243. Pengujian ketepatan predictor (reputasi merek dan kepuasan pelanggan) menggunakan nilai Standard Error of Estimate (SEE) yang dibandingkan dengan nilai Standar Deviasi (SD) pada Tabel 5.

Tabel 5. Uji ketepatan predictor penelitian

\begin{tabular}{lll}
\hline Variabel & SEE & SD \\
\hline Loyalitas Pelanggan & & 2,479 \\
Reputasi Merek & 2,263 & 2,305 \\
Kepuasan Pelanggan & & 2,549 \\
\hline
\end{tabular}

Keterangan: Analisis Regresi Linier Berganda

$\mathrm{SEE}=$ Standard Error of Estimate $; \mathrm{SD}=$ Standard Deviation;

Nilai SEE digunakan untuk menilai kelayakan variabel predictor (independen) dalam kaitannya dengan variabel dependen. Jika nilai SEE < nilai SD, maka predictor yang digunakan untuk memprediksi variabel dependen sudah layak. Tabel 5 menunjukkan nilai SEE sebesar 2,263 < SD semua variabel predictor yaitu 2,305 (variabel reputasi merek) dan 2,549 (variabel kepuasan pelanggan). Hal ini bermakna bahwa variabel reputasi merek dan kepuasan pelanggan secara parsial layak digunakan untuk memprediksi loyalitas pelanggan.

Model persamaan regresi yang diperoleh kemudian dilakukan interpretasi dengan pengujian statistik $\mathrm{R}^{2}$, Uji F, dan Uji t. Nilai $\mathrm{R}$ square atau Koefisien Diterminasi (KD) 
menandakan besarnya pengaruh variabel independen reputasi merek dan kepuasan pelanggan terhadap loyalitas pelanggan secara bersama-sama. Nilai R square pada penelitian ini yaitu 0,184 atau $18,4 \%$, bermakna besarnya pengaruh reputasi merek dan kepuasan pelanggan secara bersama-sama terhadap loyalitas pelanggan adalah sebesar $18,4 \%$, sedangkan $81,6 \%$ dipengaruhi oleh faktor lain yang tidak diteliti. Nilai koefisien KD yang jauh dari 100\% menandakan bahwa kemampuan variabel-variabel independen untuk memprediksi variabel dependen sangat terbatas.

Selanjutnya dilakukan pengujian model dengan uji $\mathrm{F}$ dari keluaran ANOVA untuk mengetahui apakah benar variabel independen (reputasi merek dan kepuasan pelanggan) secara bersama-sama mempengaruhi variabel dependen (loyalitas pelanggan). Hasil uji ANOVA menunjukkan nilai $\mathrm{F}$ hitung adalah 10,677 > F tabel $(3,09)$, dan nilai signifikansi sebesa r $0,000<0,05$, maka $\mathrm{H}_{0}$ ditolak atau $\mathrm{H}_{1}$ diterima. Hal ini bermakna terdapat pengaruh yang signifikan dari variabel independen (reputasi merek dan kepuasan pelanggan) terhadap variabel dependen (loyalitas pelanggan). Artinya model regresi tersebut sudah layak dan benar untuk memprediksi pengaruh variabel reputasi merek dan kepuasan pelanggan secara bersama-sama terhadap loyalitas pelanggan.

Hasil analisis menunjukkan bahwa penelitian ini mendukung teori yang menyatakan reputasi merek dan kepuasan pelanggan mempengaruhi loyalitas pelanggan. Kepuasan pelanggan dan reputasi merek adalah penentu dari loyalitas pelanggan (Selnes, 1993). Peneliti Andreassen (1994) menyatakan bahwa reputasi merek mempunyai pengaruh pada kepuasan dan loyalitas pelanggan, sedangkan literatur-literatur lain menyebutkan bahwa kepuasan pelanggan adalah salah satu penentu utama dari loyalitas pelanggan (Anderson and Sullivan, 1993; Andreassen, 1994; Andreassen and Lindestad, 1998; Chi and Qu, 2008; Chiou et al., 2002; Cronin and Brady, 2000; James L Heskett and Sasser, 2010; Lin and Wang, 2006; Mcdougall and Levesque, 2000; Parasuraman et al., 1985).

Hasil penelitian menunjukkan bahwa reputasi merek berpengaruh positif dan signifikan terhadap loyalitas pelanggan produk " $X$ " di kota Medan. Hal ini memberi dukungan pada penelitian Sunarto (2006) yang menyatakan bahwa reputasi merek berpengaruh positif dan signifikan terhadap loyalitas pelanggan nasabah BRITAMA BRI Kendal (Sunarto, 2006). Penelitian Selnes (1993) terhadap para konsumen dari empat perusahaan yang berbeda (asuransi jiwa, perusahaan telepon, universitas dan pemasok) juga menunjukkan adanya pengaruh positif dari reputasi merek terhadap loyalitas pelanggan. Kepuasan pelanggan tidak 
hanya dipengaruhi oleh kualitas produk atau jasa tetapi juga reputasi merek. Dalam situasi di mana isyarat intrinsik dari produk atau jasa yang ambigu, reputasi merek merupakan pendorong terkuat loyalitas pelanggan dibandingkan dengan kepuasan pelanggan (Selnes, 1993). Andreassen (1994) menyatakan bahwa reputasi merek menjadi sebuah issue dari sebuah sikap dan kepercayaan kepada penghargaan merek, imej dan kepuasan serta loyalitas pelanggan. Disamping itu reputasi merek adalah merupakan suatu faktor penting yang mempengaruhi kepuasan terhadap perusahaan dan loyalitas. Penelitian ini berhasil mengembangkan beberapa indikator untuk mengukur reputasi merek, yaitu nama baik, reputasi dibanding pesaing, dikenal luas, dan kemudahan diingat (Andreassen, 1994). Penelitian lebih lanjut juga menyimpulkan bahwa reputasi merek memainkan peran penting dalam mengembangkan loyalitas pelanggan (Andreassen and Lindestad, 1998).

Penelitian oleh Cretu dan Brodie (2009) menunjukkan peran diferensial brand image dan reputasi merek pada kualitas yang dirasakan, nilai pelanggan, dan loyalitas pelanggan. Brand image mempengaruhi persepsi kualitas produk dan layanan tambahan, sedangkan tindakan reputasi merek di luar citra merek, memperkirakan nilai pelanggan dan loyalitas pelanggan. Efek dari reputasi merek juga divalidasi pada sampel yang berbeda. Hasil menunjukkan pentingnya pengelolaan aspek brand equity, brand image, dan reputasi merek karena dampak yang berbeda terhadap persepsi kualitas, nilai pelanggan, dan loyalitas pelanggan. Hasil juga menunjukkan bahwa perusahaan tidak harus membatasi untuk berinvestasi hanya dalam citra merek. Mempertahankan dan meningkatkan reputasi merek dapat memiliki dampak yang kuat pada nilai pelanggan dan loyalitas pelanggan, dan dapat menciptakan keunggulan kompetitif diferensial (Cretu and Brodie, 2009).

Kepuasan pelanggan berpengaruh positif dan signifikan terhadap loyalitas pelanggan produk "X" di kota Medan. Hasil penelitian ini mendukung penelitian yang dilakukan Crosby dan Stephens (1987) pada industri jasa perasuransian yang menyebutkan bahwa ketidakpuasan merupakan salah satu penyebab beralihnya konsumen (Crosby and Stephens, 1987). Juga penelitian Fornel (1992) yang menyebutkan bahwa pelanggan yang puas cenderung menjadi pelanggan yang loyal (Fornell, 1992). Penelitian lain yang mendukung yaitu penelitian oleh Sunarto (2006) yang menyatakan bahwa kepuasan pelanggan berpengaruh positif dan signifikan terhadap loyalitas pelanggan nasabah BRITAMA BRI Kendal (Sunarto, 2006). Hasil penelitian ini semakin diperkuat oleh penelitian (Suwarni and Mayasari, 2011) yang menyimpulkan bahwa terdapat pengaruh yang signifikan antara 
kepuasan konsumen terhadap loyalitas, yang dikarenakan harapan konsumen sesuai dengan layanan yang diberikan, sehingga konsumen menjadi loyal. Jadi, meskipun kepuasan pelanggan tidak menjamin pembelian kembali oleh pelanggan tapi tetap saja memegang peranan yang sangat penting dalam memastikan loyalitas pelanggan. Hal ini telah disampaikan oleh Singh (2006) yaitu kepuasan pelanggan merupakan faktor penentu langsung dalam loyalitas pelanggan. Oleh karena itu, perusahaan harus selalu berusaha untuk memastikan bahwa pelanggan mereka sangat puas (Singh, 2006). Fornell (1992) mengatakan kepuasan pelanggan yang tinggi akan menghasilkan peningkatan loyalitas bagi perusahaan dan pelanggan akan kurang rentan terhadap tawaran dari kompetisi (Fornell, 1992). Pandangan ini juga disampaikan peneliti lain yang mengatakan bahwa kepuasan positif berhubungan dengan niat pembelian kembali, kemungkinan merekomendasikan produk atau jasa, loyalitas dan profitabilitas (Anton, 1997). Pelanggan setia akan membeli dari perusahaan dalam waktu yang lama (Evans and Lindsay, 1996). Guiltinan et al. mengatakan bahwa pelanggan yang puas lebih mungkin akan mengulangi dan bahkan menjadi loyal pelanggan yang loyal (Guiltinan et al., 1997). Evans dan Lindsay mengatakan perusahaan dengan pelanggan yang puas memiliki kesempatan yang baik untuk mengubahnya menjadi pelanggan setia yang membeli selama jangka waktu lama (Evans and Lindsay, 1996).

Penelitian menunjukkan bahwa reputasi merek dan kepuasan pelanggan secara bersamasama mempunyai pengaruh yang signifikan terhadap loyalitas pelanggan apotek terhadap produk "X" di kota Medan. Hal ini mendukung penelitian dari Hermawan (2011) yang menyatakan bahwa loyalitas konsumen dipengaruhi baik secara langsung maupun secara tidak langsung oleh variabel kualitas produk, kepuasan konsumen dan reputasi merek (Hermawan, 2011). Anderson (1994) menyatakan bahwa tingkat kepuasan pelanggan meningkatkan loyalitas dengan membangun reputasi merek yang positif (Anderson, 1994). Studi Andreassen (1994) juga menegaskan bahwa ada hubungan positif antara reputasi merek dan kepuasan pelanggan, yang mengarah ke loyalitas (Andreassen, 1994).

\section{KESIMPULAN}

Reputasi merek dan kepuasan pelanggan secara parsial mempunyai pengaruh yang positif dan signifikan terhadap loyalitas pelanggan, masing-masing sebesar 0,32 dan 0,24. Reputasi merek dan kepuasan pelanggan secara bersama-sama juga mempunyai pengaruh yang positif dan signifikan sebesar $18,4 \%$ terhadap loyalitas pelanggan produk " $\mathrm{X}$ " pada 
apotek di kota Medan. Model persamaan regresi yang dihasilkan yaitu $\mathrm{Y}=11,318+0,32 \mathrm{X}_{1}+$ $0,243 \mathrm{X}_{2}$. Dimana $\mathrm{Y}=$ loyalitas pelanggan; $\mathrm{X}_{1}=$ reputasi merek; dan $\mathrm{X}_{2}=$ kepuasan pelanggan .

\section{UCAPAN TERIMAKASIH}

Ucapan terima kasih disampaikan kepada PBF X cabang Medan dan apotek-apotek di kota Medan yang telah memberikan kesempatan sebagai tempat penelitian.

\section{DAFTAR PUSTAKA}

Anderson, E. W. (1994). Cross-category variation in customer satisfaction and retention. Marketing Letters, 5(1), 19-30.

Anderson, E. W., \& Sullivan, M. W. (1993). The Antecedents and Consequences of Customer Satisfaction for Firms. Marketing Science, 12(2), 125-143.

Andreassen, T. W. (1994). Satisfaction, Loyalty and Reputation as Indicators of Customer Orientation in the Public Sector. International Journal of Public Sector Management, $7(2), 16-34$.

Andreassen, T. W., \& Lindestad, B. (1998). The effect of corporate image in the formation of customer loyalty. Journal of Service Research, 1(1), 82-92.

Anton, J. (1997). Customer relationship management: Making hard decisions with soft numbers. Journal of Leisure Research, 29(3), 355-358.

Bae, Y. (2011). Modeling the Determinants of the Customer Satisfaction-Customer Loyalty Association: Theory and Empirical Evidence. University of Iowa, Lowa.

Chi, C. G. Q., \& Qu, H. (2008). Examining the structural relationships of destination image, tourist satisfaction and destination loyalty: An integrated approach. Tourism Management, 29(4), 624-636.

Chiou, J. ., Droge, C., \& Hanvanich, S. (2002). Does customer knowledge affect how loyalty 
is formed? Journals.Sagepub.Com, 5(2), 113-124.

Cretu, A. E., \& Brodie, R. J. (2009). Brand image, corporate reputation, and customer value. Emerald Group Publishing Limited, 15, 263-387.

Cronin, J. J., \& Brady, M. K. (2000). Assessing the effects of quality, value, and customer satisfaction on consumer behavioral intentions in service environments. Journal of Retailing, 76(2), 193-218.

Crosby, L. A., \& Stephens, N. (1987). Effects of Relationship Marketing on Satisfaction, Retention, and Prices in the Life Insurance Industry. Journal of Marketing Research, 24(4), 404-411.

Eggert, A., \& Ulaga, W. (2002). Customer perceived value: A substitute for satisfaction in business markets? Journal of Business \& Industrial Marketing, 17(2-3), 107-118.

Evans, J. R., \& Lindsay, W. M. (1996). The Management and Control of Quality, 3rd ed. West Publishing Company, St Paul.

Fornell, C. (1992). A National Customer Satisfaction Barometer: The Swedish Experience. Journal of Marketing, 56(1), 6-21.

Guiltinan, J. P., Paul, G. W., \& Madden, T. J. (1997). Marketing Management: Strategies and Programs, 6th ed. McGraw-Hill, New York.

Hallowell, R. (1996). The relationships of customer satisfaction, customer loyalty, and profitability: an empirical study. International Journal of Service Industry Management, $7(4), 27-42$.

Hanan, M., \& Karp, P. (1991). Customer Satisfaction: How to Maximaze, Measure and Market your company's Ultimate Product. American Management Association, New York. 
Hermawan, B. (2011). Pengaruh Kualitas Produk Terhadap Kepuasan, Reputasi Merek dan Loyalitas Konsumen Jamu Tolak Angin PT. Sido Muncul. Jurnal Manajemen Teori Dan Terapan, 4(2). https://www.e-journal.unair.ac.id/JMTT/article/view/2415

Heskett, J L, \& Jones, T. O. (1994). Putting the service-profit chain to work. Harvard Business Review, 105-111. http://www.lefacteurhumain.com/wpcontent/uploads/2013/07/Putting_the_Service_Profit_Chain_to_Work.pdf

Heskett, James L, \& Sasser, W. E. (2010). The Service Profit Chain. 19-29.

Kotler, P., \& Keller, K. . (2006). Marketing Management, 12th Edition. Pearson Education, New Jersey.

Kumar, V., Batista, L., Science, R. M.-S., \& undefined 2011. (2011). The impact of operations performance on customer loyalty. Pubsonline.Informs.Org, 3(2), 158-171.

Lin, H. H., \& Wang, Y. . (2006). An examination of the determinants of customer loyalty in mobile commerce contexts. Information \& Management, 43, 271-282.

Mcdougall, G. H. g., \& Levesque, T. (2000). Customer satisfaction with services: putting perceived value into the equation. Journal of Services Marketing, 14(5), 392-410.

Mittal, V., Kamakura, W. A., of marketing research, W. A. K.-J., \& undefined 2001. (2001). Satisfaction, repurchase intent, and repurchase behavior: Investigating the moderating effect of customer characteristics. Journal of Marketing Research, XXXVIII(1), 131-142.

Musanto, T. (2004). Faktor-faktor kepuasan pelanggan dan loyalitas pelanggan: Studi kasus pada CV. Sarana Media Advertising Surabaya. Jurnal Manajemen \& Kewirausahaan, 6(2), 123 - 136. http://ced.petra.ac.id/index.php/man/article/view/16140

Parasuraman, A., Zeithaml, V. A., \& Berry, L. L. (1985). A Conceptual Model of Service 
Quality and Its Implications for Future Research. Journal of Marketing, 49(4), 41.

Putra, C. G. . (2011). Analisis Kepuasan Pelanggan pada Perusahaan Daerah Air Minum (PDAM) di Kabupaten Jembrana. Thesis, Program Pascasarjana Universitas Udayana.

Selnes, F. (1993). An examination of the effect of product performance on brand reputation, satisfaction and loyalty. European Journal of Marketing, 27(9). https://www.ingentaconnect.com/content/mcb/007/1993/00000027/00000009/art00002

Singh, H. (2006). The Importance of customer satisfaction in relation to customer loyalty and retention by harkiranpal singh May 2006 UCTI working paper. UCTI Working Paper, May, 6.

Sunarto. (2006). Analisis faktor-faktor yang mempengaruhi loyalitas pelanggan dan dampaknya terhadap keungggulan bersaing (Studi pada Tabungan Britama BRI Kanca Kendal), Thesis, Program Pascasarjana Universitas Diponegoro.

Suwarni, \& Mayasari, S. D. (2011). Pengaruh kualitas produk dan harga terhadap loyalitas melalui kepuasan konsumen. Jurnal Ekonomi Bisnis, 16(1). http://fe.um.ac.id/wpcontent/uploads/2009/10/10-Suwarni.pdf

Tjiptono, F. (2002). Manajemen Pemasaran. Penerbit Andi, Yogyakarta. 